'Cultures et Développements'

Cultures et Développements, Revue internationale des Sciences du Développement (Université Catholique de Louvain), publie des travaux originaux de représentants parmi les plus qualifiés des sciences du développement. Instrument de promotion scientifique du monde insuffisamment développé, sa chronique fournit une information scientifique concernant le tiers monde et l'aide à la coopération. De plus, grâce à la collaboration d'un vaste réseau de correspondants, elle propose des analyses et des normes d'appréciation sur le mouvement des idées et des faits, l'évolution culturelle, sociale, politique et économique qui engagent l'avenir immédiat des pays neufs. Des comptes rendus critiques et une bibliographie générale enregistrent les manifestations nombreuses et diversifiées de l'intérêt qui se fait jour dans toutes les branches de savoir pour les problèmes de développement. Cultures et Développements entend s'ouvrir largement aux collaborations étrangères, de quelque provenance confessionnelle ou idéologique qu'elles soient, pourvu qu'elles s'alignent sur une exigence partagée de rigueur scientifique et d'objectivité critique.

Cultures et Développements paraît quatre fois par an. Secrétaire de rédaction: A. Lecointre, 2A Van Evenstraat, Louvain, Belgique; tarifs d'abonnement - Belgique, soo $F B$; Étranger, 550 FB. Les abonnements peuvent se régler au nom de Cultures et Développement, Société générale de Banque Louvain, compte no 48. I 19.

\title{
West African Linguistic Society: Recent Publications
}

The Benue-Congo Comparative Wordlist, Volumes I and II, includes 198 languages, with representatives of the Plateau, Jukunoid, Cross River, and Bantoid branches of the BenueCongo language group. Responses from over I 50 glosses are presented in $\mathrm{I} 7 \mathrm{f}$ entries with identification of likely cognates among languages and comments on the distribution of the various roots. Volume I, edited by Kay Williamson and Kiyoshi Shimizu, appeared in 1968 and includes entries for English glosses A-L; Volume II (M-Z), edited by T. L. Cook, will appear in July 1969.

Benue-Congo Noun Class Systems, edited by Jan Voorhoeve and P. P. De Wolf, presents descriptions of the noun class systems of thirty-seven languages ( $P$ art $I$ ) and a comparative study of these systems (Part II). This volume appeared in March 1969.

All three volumes are the product of the activities of the Benue-Congo Working Group of the West African Linguistic Society. Their purpose is to bring together and to analyse data relevant to an investigation of the position of Bantu within the Benue-Congo group and of the internal relationships (sub-groupings) of the Benue-Congo languages in general.

The Noun Class Systems volume may be ordered from the Afrika Studiecentrum, University of Leiden, Stationsplein Io, Leiden, The Netherlands. The price is U.S. $\$ 2.00$ or I 6s. $8 d$. (sterling). A special reduced price of U.S. \$1.20 or Ios. (sterling) is offered to members of the West African Linguistic Society and to educational institutions.

The Comparative Wordlist may be ordered from the West African Linguistic Society, University of Ibadan, Ibadan, Nigeria. The prices, including surface postage, are as follows:

\section{Both volumes One volume only}

$\begin{array}{lll}£ \text { Nigerian } & £ 3.6 s . & £ 2 . \\ £ \text { Sterling } & £ 4 . & £ 2 . \text { Ios. } \\ \text { U.S. } \$ & 10.00 & 6.25\end{array}$

For members of the West African Linguistic Society:

$\begin{array}{lll}£ \text { Nigerian } & £ 3 . & \oint_{1} .15 s . \\ £ \text { Sterling } & £ 3.125 . & £ 2.5 s . \\ \text { U.S. } \$ & 9.00 & 5.60\end{array}$

